\title{
Presence of glycosaminoglycans in purified AA type amyloid fibrils associated with juvenile rheumatoid arthritis
}

\author{
JEANETTE H MAGNUS, ${ }^{1}$ GUNNAR HUSBY, ${ }^{1}$ AND SVEIN O KOLSET ${ }^{2}$ \\ From the ${ }^{1}$ Department of Rheumatology, Institute of Clinical Medicine, and the ${ }^{2}$ Institute of Medical Biology, \\ University of Tromsø, 9012 Trømso, Norway
}

SUMMARY Previous studies have strongly suggested an association between glycosaminoglycans and tissue deposits of amyloid. The present study was aimed at studying this association in purified preparations of hepatic amyloid fibrils obtained from human AA type secondary amyloidosis. Glycosaminoglycans were isolated by gradient ion exchange chromatography of purified amyloid fibrils treated with pronase. Degradation with specific enzymes identified the glycosaminoglycans as chondroitin sulphate, dermatan sulphate, and heparin/heparan sulphate. The total amount of glycosaminoglycans specifically coisolated with the amyloid fibrils was 15 $\mu \mathrm{g} / \mathrm{mg}$ fibril weight. The presence of glycosaminoglycans in amyloid may play a part in the incorporation of structurally diverse protein precursors into amyloid fibrils of identical ultrastructure.

Key words: amyloidosis, protein AA.

Amyloidosis is a heterogeneous disorder both with regard to its clinical expression and the chemical composition of the amyloid deposits. ${ }^{1}$ Despite this heterogeneity all forms of amyloid have similar or identical ultrastructural and tinctorial properties, including typical metachromasia. ${ }^{2}$ The proteinaceous fibrils are the unique component of all amyloid deposits. It has been shown that different proteins can make up such fibrils and that there is a close relation between the chemical composition of the amyloid fibrils and the clinical category of amyloid disease. ${ }^{3}$ The fibrils are thus made up by immunoglobulin light chain (AL) proteins or fragments in primary or myeloma associated amyloidosis, ${ }^{4}$ whereas protein AA is the major fibril component in secondary amyloidosis. ${ }^{5}$ The precursor for protein $A A$ is serum amyloid $A^{6}$ as shown by recent experiments performed in our laboratory. ${ }^{7}$ Variants of prealbumin represent the fibril protein in various familial forms of amyloidosis. ${ }^{8}$

Accepted for publication 25 July 1988.

Correspondence to $\mathrm{Dr}$ Jeanette $\mathrm{H}$ Magnus, Department of Rheumatology, Institute of Clinical Medicine, University of Tromsø, PO Box 977, N-9001 Troms $ø$, Norway.
The role of glycosaminoglycans or mucopolysaccharides as a possible constituent in amyloid was suggested by Oddi in 1894 . $^{9}$ Investigations undertaken by Bitter and Muir in 1966 further suggested that heparan sulphate could be involved in the deposition of protein in insoluble fibrillar form in the amyloid lesions. ${ }^{10}$

The water extraction method of Pras and coworkers has become the standard method for isolation of amyloid fibrils from affected tissues. ${ }^{11}$ We used this method to investigate the possible association of glycosaminoglycans with AA type human amyloid fibrils.

\section{Materials and methods}

SOURCE OF AMYLOID FIBRILS

Protein AA type amyloid fibrils were prepared from the liver of a 12 year old male patient, who had amyloidosis associated with juvenile rheumatoid arthritis. The amyloid tissue stained with Congo red and showed typical green birefringence when examined by polarisation microscopy.

Normal human liver was obtained at necropsy and used for control. The organs were kept at $-20^{\circ} \mathrm{C}$ before use. 
PURIFICATION OF AMYLOID FIBRILS

The hepatic amyloid fibrils were isolated according to the method of Pras et al, ${ }^{11}$ with a small modification. ${ }^{12}$ Briefly, the amyloid fibrils were isolated by extractions with distilled water after repeated washing of homogenised tissue with physiological saline until the optical density at $280 \mathrm{~nm}$ in the supernatant was negligible, usually seven to 10 times. The third and fourth $0.15 \mathrm{M}$ saline washes also contained $3.68 \mathrm{~g}$ sodium citrate and $0.395 \mathrm{~g}$ trometamol (TRIS) $\mathrm{HCl}$ in $250 \mathrm{ml}$ saline. The saline washes and the first distilled water supernatant were not studied further, while the remaining aqueous supernatants were lyophilised and kept at $-20^{\circ} \mathrm{C}$ until used.

The normal liver was subjected to the same extraction procedure.

\section{CONGO RED ABSORPTION}

The method described by Pras et al was used for Congo red absorption experiments. ${ }^{11}$ Briefly, 2.0 $\mathrm{mg}$ of lyophilised water supernatant from amyloid laden and normal liver tissues was suspended by sonication in $1 \mathrm{ml}$ of distilled water and mixed with $5 \mathrm{ml}$ of a $0.1 \mathrm{mg} / \mathrm{ml}$ solution of Congo red in physiological saline, stirred for two hours, and then centrifuged at $1000 \mathrm{~g}$ for 10 minutes. The optical densities of the supernatants were read at $490 \mathrm{~nm}$ in a spectrophotometer.

\section{GEL FILTRATION}

Protein AA was purified by gel filtration of lyophilised amyloid fibrils under dissociating conditions as previously described in detail. ${ }^{13}$

\section{IMMUNOLOGICAL CHARACTERISATION}

Double diffusion in $1 \%$ agarose gel was used for immunological characterisation of crude alkali degraded amyloid fibrils of amyloid and purified amyloid protein fractions obtained by gel filtration. ${ }^{13}$

Antisera to $\mathrm{AA}, \mathrm{AL}$, and prealbumin related amyloid were produced in rabbits by immunisation with amyloid fibrils degraded with $0.1 \mathrm{M} \mathrm{NaOH}$ and absorbed as previously described. ${ }^{14}$

ISOLATION OF GLYCOSAMINOGLYCANS Lyophilised amyloid fibrils were dissolved $(6 \mathrm{mg} / \mathrm{ml})$ in $0.2 \mathrm{M}$ trometamol $\mathrm{HCl} \mathrm{pH} 8.0$ and digested with pronase $0.2 \mathrm{mg} / \mathrm{ml}$ at $36^{\circ} \mathrm{C}$ for 18 hours. The digested fibrils and the digest from the corresponding extract of the normal liver were chromatographed on a diethylaminoethyl (DEAE)-Sephacel ion exchange column. ${ }^{15}$ The column was eluted with $0.05 \mathrm{M}$ sodium acetate buffer $\mathrm{pH} 4.0$ with a gradient from $0.2 \mathrm{M} \mathrm{NaCl}$ to $2.0 \mathrm{M} \mathrm{NaCl}$. Selected fractions were pooled after determination of hexuronic acid, $\overrightarrow{\vec{*}}$ dialysed against distilled water, and lyophilised.

The lyophilised polysaccharide fractions were dissolved in $0.5 \mathrm{ml}$ phosphate buffered saline $\mathrm{pH}$ $7 \cdot 3$.

\section{CARBAZOLE REACTION}

Hexuronic acid was determined by the carbazole $\vec{\circ}$ method described by Bitter and Muir ${ }^{16}$ with glucuronolactone as standard.

\section{ENZYMATIC STUDIES}

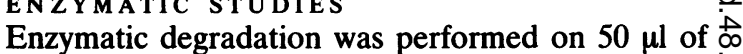
the lyophilised polysaccharide material after ion $\omega$ exchange chromatography. Chondroitinase AC (EC $\underset{G}{\mathrm{~N}}$ 4.2.2.5) was obtained from Sigma, chondroitinase $\mathrm{ABC}$ (EC 4.2.2.4) and heparitinase (EC 4.2.2.8) from Seikagaku Kogyo, Tokyo, Japan. Galactosaminoglycans were degraded by sequential incubations with chondroitinase $\mathrm{AC}$ and chondroitinase $\Omega$ $\mathrm{ABC}$ in $0.05 \mathrm{M}$ trometamol $\mathrm{HC} 1 \mathrm{pH} 8.0$ containing $0.05 \mathrm{M}$ sodium acetate, $0.05 \mathrm{M} \mathrm{NaCl}$, and $0.1 \mathrm{mg} / \mathrm{ml}$ of bovine serum albumin. ${ }^{17}$ To the incubation mixtures (generally $450 \mu \mathrm{l}$ ) were added $50 \mu \mathrm{l}$ sample and 0.05 unit of the respective enzymes. Each separate incubation was performed for one hour at $37^{\circ} \mathrm{C}$. The absorbance at $232 \mathrm{~nm}$ was read in a spectrophotometer.

Polysaccharides containing $N$-sulphated glucosa- $\overline{\bar{O}}$ mine residues - that is, heparin or heparan sulphate, $\exists$ were degraded by incubation with heparitinase $e^{1819}$ in $3 \mathrm{mM}$ sodium acetate buffer $\mathrm{pH} 7.0$ containing 3 . mM calcium chloride. Generally, $450 \mu \mathrm{l}$ of this buffer was used with $50 \mu \mathrm{l}$ sample and 0.002 unit of $\bar{\alpha}$ heparitinase. The samples were incubated for one hour at $43^{\circ} \mathrm{C}$, and the absorbance at $232 \mathrm{~nm}$ was read in a spectrophotometer.

\section{Results}

\section{CONGO RED STAINING AND ABSORPTION} The amyloid laden liver from the patient was heavily $N$ infiltrated with material showing typical yellow- $N$ green birefringence as demonstrated by polarisation $\mathrm{N}$ microscopy of sections stained with Congo red. The $\omega$ normal organ was negative in this respect. The optical density at $280 \mathrm{~nm}$ in the second aqueous $\stackrel{\varrho}{\leftarrow}$ supernatant of the amyloidotic liver exceeded $1.5, \Phi$ whereas that of the corresponding normal organ was ? less than $0 \cdot 5$. This particular distilled water supernatant from the amyloid laden liver showed the $\stackrel{\vec{D}}{\vec{D}}$ highest degree of absorbance of Congo red (data not $\frac{\rho}{P}$ shown) and thus contained the largest amounts of $\stackrel{\mathbb{Q}}{\varrho}$ amyloid fibrils. The second water supernatant was therefore selected for further studies. 
IMMUNOLOGICAL STUDIES

Double diffusion using antisera to AA showed reactivity with crude degraded amyloid fibrils and purified protein AA from the patient. These amyloid preparations did not react with antisera to amyloid of immunoglobulin or prealbumin origin.

The normal tissue preparations did not react with the antisera to AA or any other amyloid protein. The protein AA nature of the amyloid from the patient was also confirmed by amino acid studies of the purified protein (data not shown).

\section{COISOLATION OF POLYSACCHARIDES AND}

HEPATIC AMYLOID FIBRILS

Figure 1 shows the elution profile of carbazole reactive polysaccharides obtained by gradient ion exchange chromatography of amyloid fibrils from the patient after treatment with pronase. One small and three larger peaks were obtained at molarities of 0.60 (peak 1), 0.73 (peak 2), 0.80 (peak 3), and 0.93 (peak 4). This pattern was consistent throughout several runs on DEAE-Sephacel.

Table 1 shows the quantities of carbazole positive polysaccharides eluted in the various peaks. More than half of the polysaccharides was eluted at $0.73 \mathrm{M}$ $\mathrm{NaCl}$ (peak 2), but a considerable amount (approximately $20 \%$ ) was eluted in the position corresponding to the peak of a heparin standard, indicating a relatively high degree of sulphation or large molecular size of the polysaccharide associated with amyloid fibrils, or both (Fig. 1).
The total amount of such polysaccharides coisolated with amyloid fibrils extracted in the second water supernatant was approximately $15 \mu \mathrm{g} / \mathrm{mg}$ of lyophilised fibrils (Table 1). A corresponding extract from normal human liver yielded only trace amounts of carbazole positive polysaccharides after ion exchange chromatography and showed virtually no peaks corresponding to those of the amyloid material (Fig. 1).

\section{ENZYMATIC CHARACTERISATION OF AMYLOID ASSOCIATED \\ GLY COSAMIN O GLYCANS}

Separate samples of the amyloid associated polysaccharide material obtained from the four ion exchange chromatography peaks (Fig. 1) were subjected to heparitinase and to sequential treatment with chondroitinase $\mathrm{AC}$ and chondroitinase $\mathrm{ABC}$. Table 2 shows the relative amounts of degradable material using the respective enzymes.

The glycosaminoglycans which are degraded by chondroitinase $\mathrm{AC}$ and chondroitinase $\mathrm{ABC}$ represent chondroitin sulphate and dermatan sulphate, and more than $60 \%$ of the total polysaccharides is accounted for by these glycosaminoglycans. In peaks 3 and 4 the large amount of material degraded by chondroitinase $\mathrm{ABC}$ representing dermatan sulphate was particularly noted. The amount of heparin/heparan sulphate as shown by heparitinase degradation varied from $20 \%$ to approximately $40 \%$ in the four peaks. The highest proportion of

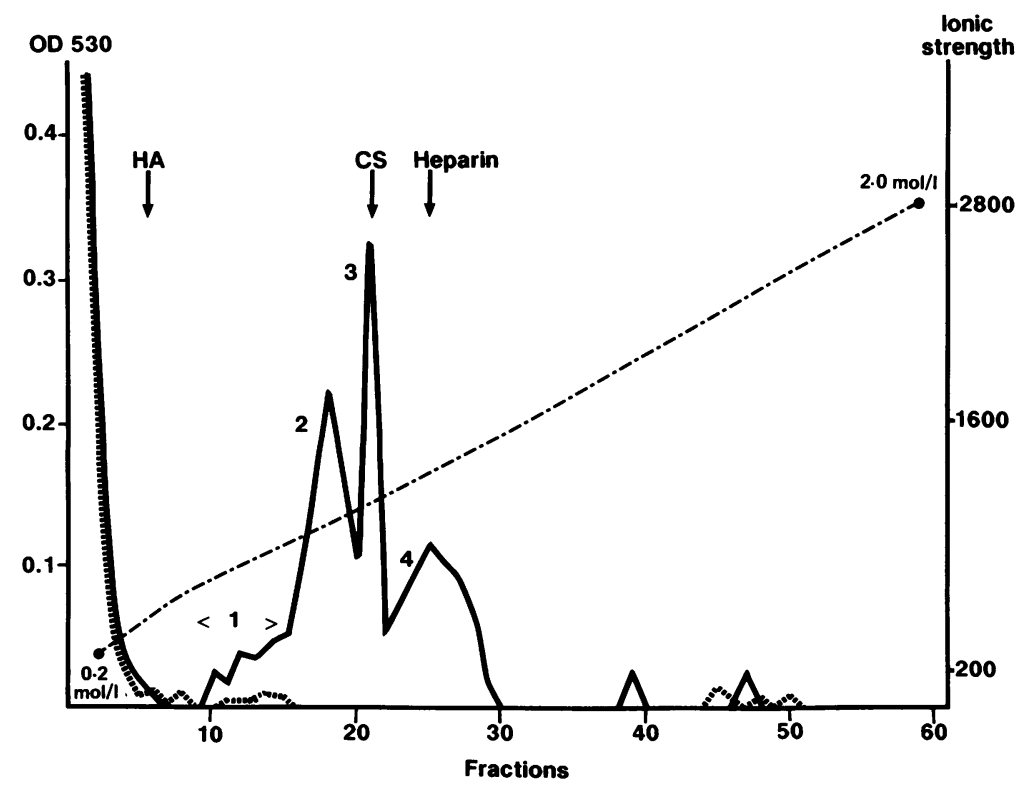

Fig. 1 Carbazole positive material (glycosaminoglycans) eluted by gradient DEAE-Sephacel ion exchange chromatography of AA type amyloid fibrils (and corresponding normal tissue extract (- - - ) treated with pronase. The molarity range of the linear $\mathrm{NaCl}$ gradient was 0.2-2.0 molll (---). . Fractions were pooled according to the four peaks indicated on the figure. $\boldsymbol{H A}=$ hyaluronic acid; $C S=$ chondroitin sulphate. 
Table 1 Amount of carbazole positive amyloid associated polysaccharide eluted by DEAE-Sephacel ion exchange chromatography

\begin{tabular}{|c|c|c|c|c|}
\hline Peak No* & $\begin{array}{l}\text { Molarity } \\
\text { of peak } \\
\text { fraction }\end{array}$ & $\begin{array}{l}\text { Absorbance } \\
\text { at } 530 \mathrm{~nm} \text { in } \\
50 \mu \mathrm{l} \text { sample }\end{array}$ & $\begin{array}{l}\text { Polysaccharidest } \\
\mu g(\%)\end{array}$ & $\begin{array}{l}\text { Polysaccharides } \\
\text { expressed as } \mu \mathrm{g} / \mathrm{m} \\
\text { of lyophilised } \\
\text { amyloid fibrils }\end{array}$ \\
\hline 1 & $0 \cdot 60$ & 0.024 & $53.4(11.4)$ & $1 \cdot 7$ \\
\hline 2 & 0.73 & $0 \cdot 155$ & $258 \cdot 0(55 \cdot 1)$ & $8 \cdot 6$ \\
\hline 3 & $0 \cdot 80$ & 0.026 & $57.6(12 \cdot 3)$ & 1.9 \\
\hline Total & & & $468 \cdot 6$ & $15 \cdot 5$ \\
\hline
\end{tabular}

* See Fig. 1.

†Glucuronolactone was used as standard.

Table 2 Relative amounts* of degradation products after enzymatic treatment of polysaccharide fractions obtained by ion exchange chromatography, determined by absorbance at $232 \mathrm{~nm}$

\begin{tabular}{lrllll}
\hline Enzyme used & Peak & 1十 & Peak & Peak & Peak 4 \\
\hline Heparitinase & 37.2 & 38.6 & 24.8 & 21.3 \\
Chondroitinase AC & 57.8 & 61.4 & $55 \cdot 2$ & 41.3 \\
Chondroitinase ABC & 5.0 & & 20.0 & 35.6
\end{tabular}

*Percentage of total absorbance at $232 \mathrm{~nm}$ after heparitinase and chondroitinase $\mathrm{ABC}$ treatment.

†See Fig. 1.

heparin/heparan sulphate was found in the ion exchange chromatography peak 2 (Fig. 1), containing $55 \%$ of the total content of carbazole positive material (Table 1) of this AA type hepatic amyloid fibril preparation.

\section{Discussion}

More than a century ago it was suggested that amyloid was mainly a proteinaceous material. ${ }^{20}$ It should be remembered, however, that Virchow who created the term amyloid in 1854 based this on its starch-like staining with iodine. ${ }^{21}$ Later on, several investigators emphasised the specific association between amyloid and polysaccharides. ${ }^{1022} 23$ Pras and coworkers suggested the presence of nonprotein material (heparitin sulphate and chondroitin sulphate B) in water extracted amyloid. ${ }^{24}$ Furthermore, studies on experimental amyloidosis have shown a clear temporal relation between the in situ occurrence of glycosaminoglycans and the deposition of amyloid. ${ }^{25}$ Indeed the accumulation of glycosaminoglycans even appears to precede the formation of detectable amyloid fibrils. Snow and Kisilevsky also demonstrated a close ultrastructural relation between amyloid fibrils and glycosaminoglycans in tissue sections, and enzymatic treatment 3 by the sections indicated the presence of chondroitin sulphate and heparin/heparan sulphate. ${ }^{26}$

In the present work we confirmed the specific $\overrightarrow{0}$ association of polysaccharides with AA type, human 0 hepatic amyloid. Using the standard method for purification of amyloid fibrils ${ }^{11}$ we have shown here that significant amounts of polysaccharide are coisolated with such fibrils. The evidence for this is as? follows: (a) The purification procedure for amyloid $\frac{}{\varnothing}$ fibrils $^{11}$ involves several washings of homogenised ${ }^{\varrho}$ tissue with physiological saline before the extraction of amyloid fibrils with water. The polysaccharides were specifically coisolated with the water extracted hepatic amyloid fibrils and not with the correspond-ing extract from normal liver. (b) Carbazole positive polysaccharide material was obtained by ion ex- $-\frac{0}{\sigma}$ change chromatography at elution positions charac- 3 . teristic of glycosaminoglycans. ${ }^{15}(c)$ The treatment of the polysaccharides derived from amyloid fibril with specific enzymes provided direct biochemicalo proof of their identity as glycosaminoglycans.

It appears, therefore, that glycosaminoglycans areo integrated in or intimately associated with human AA type amyloid fibrils. This is compatible with theo histochemical and structural observations by Snown and coworkers, who showed a close association between glycosaminoglycans and splenic AA type ${ }_{\sigma}^{\omega}$ amyloid fibrils in mice. ${ }^{26}$ The composition of glycosaminoglycans in amyloid deposits may vary with different clinical and chemical types of amyloidosis, $\$$ age of the affected individual, disease duration, and organs or tissues involved. This possibility is being studied further.

The role of glycosaminoglycans in the formation $\frac{\text { ? }}{\mathbb{D}}$ of amyloid fibrils has not been established. The $\stackrel{\varrho}{2}$ highly negatively charged glycosaminoglycan chains? may be involved in protein folding and thus in the 
formation of fibrils. ${ }^{27}$ It has also been suggested that glycosaminoglycans may modulate the fibril formation of other proteins, like collagen. ${ }^{28}$ Furthermore, it has recently been suggested that glycosaminoglycans may be part of the so called amyloid enhancing factor. ${ }^{29} 30$ This factor is poorly defined but appears to consist of both polysaccharide and protein. ${ }^{29}$ Amyloid enhancing factor activity is present in highly purified amyloid fibrils ${ }^{30}$ and has been shown to accelerate considerably the formation of AA experimental amyloid. ${ }^{31}$ Amyloid enhancing factor activity has been observed in tissue extracts from $\mathrm{AA}, \mathrm{AL}$, and prealbumin related amyloidosis. ${ }^{32}$

If it is assumed that glycosaminoglycans are essential for amyloid enhancing factor activity then polyanionic sugars may be a significant constituent common to amyloids of different protein composition. The striking ultrastructural homology of amyloid fibrils having such diverse protein structure may thus be caused by the presence of glycosaminoglycans as their 'common denominator'.

This work was supported by the Norwegian Council for Science and the Humanities, the Norwegian Women's Public Health Association, the Norwegian Rheumatism Council, and the Norwegian Cancer Society. The authors wish to thank Ms Sigrid Bolle and Ms Wenche Johnsen for skilful technical assistance.

\section{References}

1 Husby G, Sletten K. Chemical and clinical classification of amyloidosis 1985. Scand J Immunol 1986; 23: 253-65.

2 Kisilevsky R. From arthritis to Alzheimer's disease: current concepts on the pathogenesis of amyloidosis. Can J Physiol Pharmacol 1987; 65: 1805-15.

3 Cohen A S, Connors L H. The pathogenesis and biochemistry of amyloidosis. J Pathol 1987; 151: 1-10.

4 Glenner G G, Terry W D, Harda M, Iersky C, Page D. Amyloid fibril proteins: proof of homology with immunoglobulin light chains by sequence analysis. Science 1971; 172: 1150-3.

5 Benditt E P, Eriksen N, Hermondson M A, Ericsson L H. The major proteins of human and monkey amyloid substance: common properties including unusual $\mathrm{N}$-terminal amino acid sequences. FEBS Lett 1971; 19: 169-72.

6 Husby G, Husebekk A, Skogen B, et al. Serum amyloid A (SAA) - the precursor of protein AA in secondary amyloidosis. In: Malmendier C L, ed. Proceedings of the 4th international colloquium on atherosclerosis, Brussels. New York, London: Plenum Press (in press).

7 Husebekk A, Skogen B, Husby G, Marhaug G. Transformation of amyloid precursor SAA to protein AA and incorporation in amyloid fibrils in vivo. Scand $J$ Immunol 1985; 21: 283-7.

8 Nordlie M, Sletten K, Husby G, Ranløv P J. A new prealbumin variant in familial cardiomyopathy of Danish origin. Scand $J$ Immunol 1988; 27: 119-22.

9 Cohen A S. Constitution and genesis of amyloid. Exp Pathol 1965; 4: 218-27.

10 Bitter T, Muir H. Mucopolysaccharides of whole human spleens in generalized amyloidosis. J Clin Invest 1966; 45: 963-75.

11 Pras M, Schubert M, Zucker-Franklin D, Rimon A, Franklin E C. The characterization of soluble amyloid prepared in water. $J$ Clin Invest 1968; 47: 924-33.

12 Skinner M, Shirahama T, Cohen A S, Deal C L. The association of amyloid P-component (AP) with the amyloid fibril: an updated method for amyloid fibril protein isolation. Prep Biochem 1983; 12: 461-76.

13 Husby G, Sletten K, Michaelsen T E, Natvig J B. Antigenic and chemical characterization of non-immunoglobulin amyloid fibril proteins. Scand J Immunol 1972; 1: 393-400.

14 Husby G, Natvig J B. Immunological characterization of amyloid fibrils in tissue sections. Clin Exp Immunol 1972; 11: 357-66.

15 Hallen A. Chromatography of acidic glycosaminoglycans on DEAE-cellulose. J Chromatogr 1972; 71: 83-91.

16 Bitter T, Muir H M. A modified uronic acid carbazole reaction. Anal Biochem 1962; 4: 330-4.

17 Saito H, Yamagata T, Suzuki S. Enzymatic methods for the determination of small quantities of isomeric chondroitin sulfates. J Biol Chem 1968; 243: 1536-42.

18 Linker A, Hovingh P. Heparinase and heparitinase from flavobacteria. Methods Enzymol 1972; 28: 902-11.

19 Silverberg I, Havsmark B, Fransson L $\AA$. The substrate specificity of heparan sulphate lyase and heparin lyase from Flavobacterium heparinum. Carbohydr Res 1985; 137: 227-38.

20 Friedreich N, Kekule A. Zur Amyloidfrage. Virchows, Archiv A, Pathological Anatomy and Histology 1859; 16: 50-72.

21 Virchow R. Zur Cellulose-Frage. Virchows Archiv A, Pathological Anatomy and Histology 1854; 6: 416-26.

22 Dalferes E R Jr, Radhakrishnamurthy B, Berenson G S. Acid mucopolysaccharides of amyloid tissue. Arch Biochem Biophys 1967: 118: 284-91.

23 Dalferes E R Jr, Radhakrisnamurthy B, Berenson G S. Glycosaminoglycans in experimental amyloidosis. Proc Soc Exp Biol Med 1968; 127: 925-9.

24 Pras M, Nevo Z, Schubert M, Rotman J, Matalon R. The significance of mucopolysaccharides in amyloid. $J$ Histochem Cytochem 1971; 19: 443-8.

25 Snow A, Kisilevsky R. Temporal relationship between glycosaminoglycan accumulation and amyloid deposition during experimental amyloidosis. Lab Invest 1985; 53: 37-44.

26 Snow A, Willmer J, Kisilevsky R. A close ultrastructural relationship between sulfated proteoglycans and AA amyloid fibrils. Lab Invest 1987; 57: 687-98.

27 Linker A, Carney H C. Presence and role of glycosaminoglycans in amyloidosis. Lab Invest 1987; 57: 297-305.

28 Vogel K G, Trotter J A. The effect of proteoglycans on the morphology of collagen fibrils formed in vitro. Coll Relat Res 1987; 7: 105-14.

29 Snow A D, Kisilevsky R, Stephens C, Anastassiades T. Characterization of tissue and plasma glycosaminoglycans during experimental AA amyloidosis and acute inflammation. Lab Invest 1987; 56: 665-75.

30 Niewold T A, Hol P R, van Andel A C J, Lutz E T G, Gruys E. Enhancement of amyloid induction by amyloid fibril fragments in hamster. Lab Invest 1987; 56: 544-9.

31 Axelrad M A, Kisilevsky R, Willmer J, Chen S J, Skinner M. Further characterization of amyloid-enhancing factor. Lab Invest 1982; 47: 139-46.

32 Varga J, Flinn M S, Shirahama T, Rogers O G, Cohen A S. The induction of accelerated murine amyloid with splenic extract. Probable role of amyloid-enhancing factor. Virchows Arch [Cell Pathol] 1986; 51: 177-85. 